\title{
Susceptibility of juvenile humpback grouper Cromileptes altivelis to grouper sleepy disease iridovirus (GSDIV)
}

\author{
Ketut Mahardika ${ }^{1}$ Zafran $^{1}$, Asami Yamamoto ${ }^{2}$, Teruo Miyazaki ${ }^{2, *}$ \\ ${ }^{1}$ Gondol Research Institute for Mariculture, PO Box 140, Singaraja, Bali, Indonesia \\ ${ }^{2}$ Faculty of Bioresources, Mie University, 1515 Kamihama, Tsu, Mie 514-8507, Japan
}

\begin{abstract}
Susceptibility of juvenile humpback grouper Cromileptes altivelis to the grouper sleepy disease iridovirus (GSDIV) was examined. GSDIV-containing inocula for challenge were obtained using a filtrate of spleen tissues from donor fish (orange-spotted grouper Epinephelus coioides) infected with GSDIV. Groups injected with the primary filtrate showed lower mortalities (30 to $60 \%$ ) than groups receiving the $10^{-4}$ diluted inoculum (90 to $100 \%$ mortality). This result was contrary to the expectation that fish challenged with a higher concentration of virus would show higher mortality. Electron microscopy revealed that moribund fish receiving the $10^{-4}$ diluted inoculum displayed massive formation of typical inclusion body-bearing cells (IBCs) containing an intracytoplasmic inclusion body with many virions in the $180-200 \mathrm{~nm}$ size range propagated within a virus assembly site. In contrast, survivors in fish receiving the primary filtrate showed the formation of unusual IBCs containing an abnormal inclusion body that was characterized by the assembly of a small number of deformed virions. This impaired virus assembly appeared to prevent mortality in the challenged fish and was assumed to be due to an interferon-like effect of a previously unknown substance that was passed on to the challenged fish with the tissue filtrate from the donor fish.
\end{abstract}

KEY WORDS: Humpback grouper - Cromileptes altivelis - Grouper sleepy disease iridovirus · Tropical iridovirus $\cdot$ Inclusion body-bearing cells $\cdot$ Interferon-like effect

Resale or republication not permitted without written consent of the publisher

\section{INTRODUCTION}

Tropical iridoviruses encompass grouper sleepy disease iridovirus (GSDIV), dwarf gourami iridovirus (DGIV), African lampeye iridovirus (ALIV), sea bass iridovirus (SBIV) and red sea bream iridovirus (RSIV) (Sudthongkong et al. 2002b). The definitive symptom of a tropical iridovirus infection is the formation of inclusion body-bearing cells in the visceral organs. These viruses have induced severe epizootics with mass mortalities and large-scale economic losses in freshwater ornamental fishes and farmed marine fishes not only in tropical regions such as Indonesia, Singapore, Thailand and Taiwan, but also in Japan and Korea. Since 1992, tropical iridovirus infections have involved grouper species such as brown-spotted grouper Epinephelus tauvina farmed in Singapore (Chua et al. 1994), and Malabar grouper E. malabaricus in southern Thailand (Danayadol et al. 1997). The grouper disease was named 'sleepy grouper disease'. The causative iridovirus of Malabar grouper sleepy disease was originally tentatively named grouper iridovirus (GIV) (Miyata et al. 1997) and grouper spawner iridovirus (GSIV) (Jung et al. 1997). However, the virus was renamed 'grouper sleepy disease iridovirus' (GSDIV) (Sudthongkong et al. 2002b) since a ranavirus in the family Iridoviridae was found in Malabar grouper and also called GIV (Kasornchandra \& Khongpradit 1996, Nakajima et al. 1998). Grouper iridovirus in Taiwan (TGIV) was known to infect groupers of the genus Epinephelus (Chou et al. 1998) and hybrid groupers (red spotted grouper Epinephelus akaara $\times$ the Malabar grouper) 
(Chao et al. 2002). TGIV appears to be a member of the tropical iridovirus because it showed genetic homologies with RSIV (Chao et al. 2002).

Recently sleepy grouper disease has also occurred in orange-spotted grouper Epinephelus coioides and Bleeker's grouper E. bleekeri in pens offshore of Bali Island in Indonesia (Mahardika et al. 2001). The causative iridoviruses showed a genetic homology with RSIV and GSDIV in PCR assays based on primer sets for an ATPase gene of RSIV (Kurita et al. 1998) and of GSDIV (Sudthongkong et al. 2002b). Based on sleepy behavior, the causative iridovirus was confirmed to be GSDIV. There was concern over the possible transmission of GSDIV to humpback grouper Cromileptes altivelis, as this is an important fish species with high commercial value for the development of mariculture in Indonesia.

In the present study, infection experiments were performed to examine the susceptibility of humpback grouper to GSDIV. A tissue filtrate was obtained from orange spotted grouper moribund with the GSDIV infection and was given as inocula at different concentrations of the virus. This method was chosen because of difficulties in obtaining the in vitro cultured virus (lack of facilities for virus culture). It was expected that a high concentration of GSDIV would cause a higher mortality in fish than a low concentration. As results of the infection experiments contradicted this expectation, histopathological and electron microscopic studies were performed to compare the features of inclusion body-bearing cells (IBCs) of moribund fish and surviving fish, since the formation of IBCs was a definitive symptom of the tropical iridovirus infection (Sudthongkong et al. 2002b). This paper describes the results of the infection experiments and details features of IBCs of humpback grouper.

\section{MATERIALS AND METHODS}

Experimental fish. For infection experiments, a total of 100 humpback grouper juveniles (9 to $15 \mathrm{~g}$ ) were obtained from a fish breeder. Subsamples of these juveniles were examined by a routine PCR assay using primer set for the striped jack nervous necrosis virus (SJNNV) (Nishizawa et al. 1994) to ensure they were free of NNV (betanodavirus: nervous necrosis virus) and by a routine PCR assay to ensure they were free of GSDIV.

Virus. Portions of the spleen and kidney were removed from naturally diseased orange-spotted grouper with the GSDIV infection in 2000 and stored at $-80^{\circ} \mathrm{C}$. In the present study, due to lack of facilities for virus culture, orange-spotted grouper (55 to $60 \mathrm{~g}$ ) were used as donor fish for GSDIV propagation. GSDIV was propagated within the organs of orange-spotted grouper by intramuscular injection with a filtrate prepared from stored spleen tissues. Tissue pieces were homogenized in 10 vol phosphate-buffered saline, PBS $(-)$ in a glass homogenizer. The homogenate was centrifuged at $3000 \times g$ for $5 \mathrm{~min}$, and the supernatant was filtered $(450 \mathrm{~nm})$. The filtrate was diluted to $10^{-4}$ in PBS $(-)$ and a $0.1 \mathrm{ml}$ inoculum was injected into a donor fish. Donor fish were held in a tank (200 l at 28 to $30^{\circ} \mathrm{C}$ ). When they were moribund, the swollen spleen was removed, since previous examination at this laboratory had revealed that the spleen was the organ most severely affected with GSDIV. Removed spleens were stored at $-80^{\circ} \mathrm{C}$ and shown to contain GSDIV by a routine PCR assay using a primer set for a RSIV ATPase gene (Kurita et al. 1998).

In infection experiments, pieces of the stored spleens were homogenized in 10 vol of PBS (-) in a glass homogenizer. The homogenate was centrifuged at $3000 \times g$ for $5 \mathrm{~min}$, and the supernatant was filtered $(450 \mathrm{~nm})$. We prepared 2 inocula to obtain different concentrations of GSDIV, one (PF) consisting of the primary filtrate and the other (DI) of a $10^{-4}$ dilution. A $0.1 \mathrm{ml}$ inoculum was injected intramuscularly into the fish. A control was established whereby the fish were given only PBS (-); 2 infection experiments were performed. In the first experiment 10 fish were challenged, and in the second experiment 20 fish (see Table 1). The fish were held in tanks ( 2001 at 28 to $30^{\circ} \mathrm{C}$ ) with aeration and daily water exchange. They were fed upon commercial pellets. Moribund and dead fish were removed from the tanks and dissected. At the end of the experiments, all surviving fish and some control fish were dissected: in the second experiment, a total of 5 moribund fish in the DI group and 3 surviving fish in the PF group were used for histopathological study including electron microscopy. Parts of the visceral organs (spleen, kidney and digestive tract) were fixed in 10\% buffered formalin and processed for light microscopy. Tissue sections were stained with Mayer's hematoxylin and eosin (H\&E). The remaining parts of the spleen were fixed in $70 \%$ Karnovsky's solution, postfixed in $1 \% \mathrm{OsO}_{4}$ and processed for electron microscopy. Moreover, the spleens of 3 moribund fish in the DI group and 3 surviving fish in the PF group were processed for a routine PCR diagnosis of GSDIV. We used 3 control fish for histopathological examination.

Table 1. Cromileptes altivelis. Cumulative mortality among groupers receiving intramuscular injection of GSDIV

\begin{tabular}{|lcccccc|}
\hline & \multicolumn{3}{c}{ Expt 1 $(10$ fish $)$} & \multicolumn{3}{c|}{ Expt $2(20$ fish $)$} \\
\hline $\begin{array}{l}\text { Group } \\
\%\end{array}$ & PF & DI & Control & PF & DI & Control \\
& 30 & 90 & 0 & 60 & 100 & 0 \\
\hline
\end{tabular}




\section{RESULTS}

\section{Mortality}

The cumulative mortality in 2 infection experiments is shown in Table 1. In the first experiment, the fish group to which an inoculum of the primary filtrate had been given (primary filtrate-injected group: PF group) contained moribund fish 7 to $8 \mathrm{~d}$ after injection, with a total of $30 \%$ mortality at the end of experiment (21 d). The fish group to which an inoculum of $10^{-4}$ dilution was given (diluted inoculum-injected group: DI group) contained moribund fish 8 to $9 \mathrm{~d}$ after injection, with $90 \%$ cumulative mortality at the end of experiment (21 d). In the second experiment, the PF group showed $60 \%$ mortality and the DI group $100 \%$ mortality by the 17 th day, at which time the experiment was terminated. The surviving fish in the PF and DI groups did not display sleepy behavior and maintained a good appetite until the end of experiment. Diseased fish usually displayed loss of appetite and sleepy behavior, indicated by lying on a pectoral fin and subsequently lying on their side, just before death (Fig. 1A). It usually took 6 to $12 \mathrm{~h}$ from the onset of the sleepy behavior to death. All moribund fish displayed a slight dark coloration of the body and a markedly swollen spleen (Fig. 1B). Both control groups had no abnormal fish and no mortality.
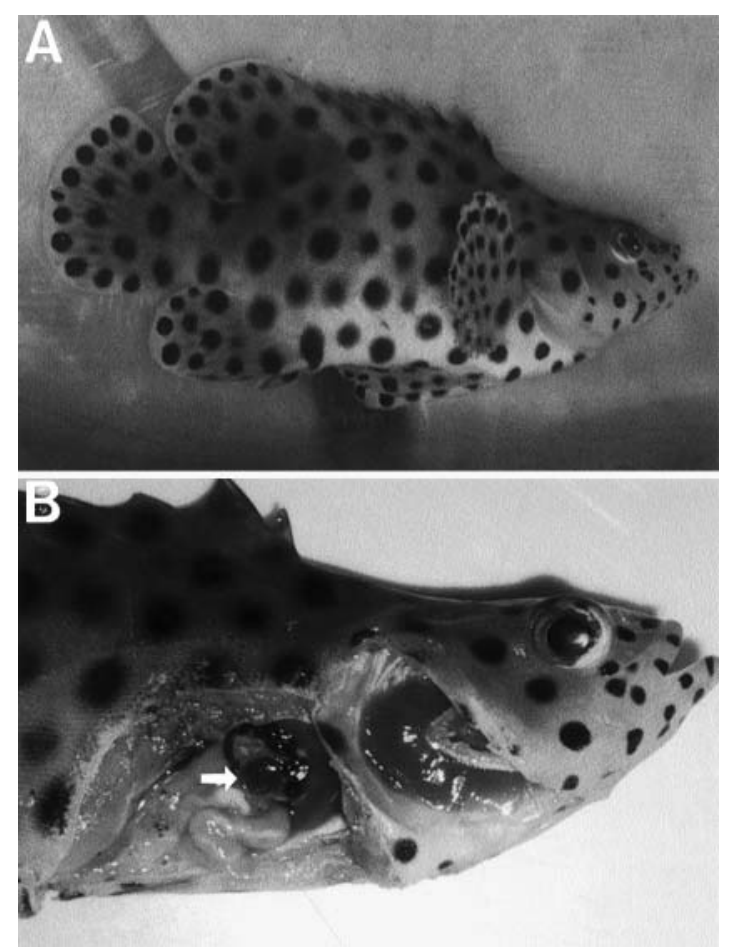

Fig. 1. Cromileptes altivelis. (A) Moribund fish lying on side on tank bottom just before death. (B) Dissected moribund fish with markedly swollen spleen (arrow)
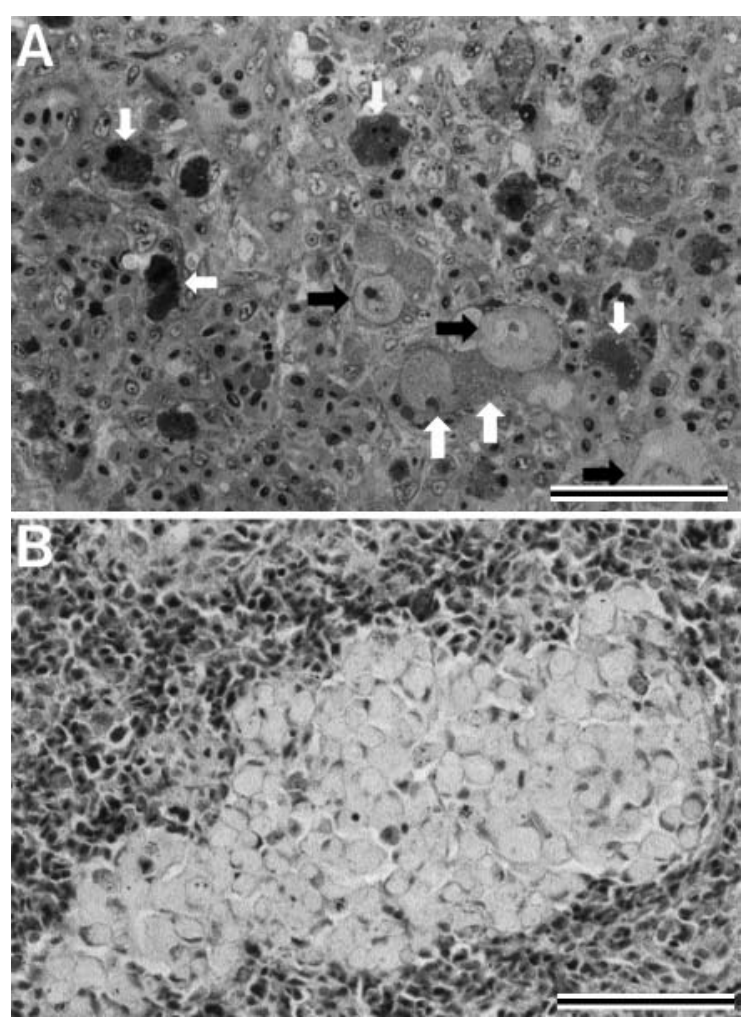

Fig. 2. Cromileptes altivelis. (A) Spleen of moribund fish injected with $10^{-4}$ diluted filtrate, showing the massive formation of inclusion body-bearing cells (IBCs) consisting of atypical IBCs like swollen cells (black arrows), mature IBCs (small white arrows) and ballooning, degenerated IBCs (large white arrows). (B) Spleen of surviving fish injected with primary filtrate, showing masses of abnormal IBCs. (H\&E; scale bars $=50 \mu \mathrm{m}$ )

\section{Histopathological signs and electron microscope features}

The spleen of moribund fish contained a massive formation of enlarged cells as inclusion body-bearing cells (IBCs) within the splenic pulps and the ellipsoid of sheathed arteries (Fig. 2A), while the digestive tracts and the kidney contained few IBCs. The early-stage IBCs appeared as hypertrophied blast-like cell with a basophilic cytoplasm and a centrally located, enlarged nucleus containing prominent nucleoli. The mature IBCs were enlarged, amoeboid in shape, and contained an entirely basophilic inclusion body. The cytoplasm and nucleus of the host cell were marginally compressed. The ballooning, degenerated IBCs contained an inclusion body with a granular appearance within a marginally compressed, narrow cytoplasm containing a pyknotic or fragmented nucleus. Moreover, atypical IBCs also appeared that looked like markedly swollen cells with a lightly stained cytoplasm 
and a swollen nucleus. In contrast, the spleen of surviving fish in the PF group contained a mass of many enlarged cells that resembled the ballooning, degenerated IBCs, but that had a clear inclusion body. These cells usually formed cellular masses (Fig. 2B). No control fish showed any histopathological changes or formation of IBCs.

Routine PCR assays revealed the ATPase-specific PCR amplicon from DNA samples of the spleen in not only moribund but also in surviving fish.

Electron microscopy (EM) revealed typical IBCs with an intracytoplasmic inclusion body, delimited from the host-cell cytoplasm by a thin membranous boundary. The early-stage IBCs contained a small inclusion body consisting of a dark matrix containing a few virions, many mitochondria, rough endoplasmic reticula (rER), ribosomes, smooth endoplasmic reticula (sER) and small dense bodies (Fig. 3A). Mature IBCs had a markedly enlarged inclusion body containing a developed virus assembly site (VAS). The host cell cytoplasm was marginally located and protruded with the boundary membrane into the inclusion body. Smaller IBCs had a nucleus containing abundant euchromatin, a cytoplasm with an increased number of organelles, and a mass of rough granules of high electron density that resembled a nucleus but that had no surrounding double membranes (Fig. 3B). Their inclusion bodies had a centrally located VAS, an abundance of rER, SER, ribosomes and mitochondria, and a mass of fine granules of high electron density. The VAS had an electron-lucent matrix with abundant fine granules, and contained many virions, hexagonal in outline and with an electron-dense core. Markedly enlarged IBCs showed a marginally compressed nucleus and cytoplasm surrounding an enlarged inclusion body (Fig. 3C,D). In the inclusion body a mass of rough granules was usually located among organelles and partially delimited with membranes, while masses of fine granules were located beside the mass of rough granules and inside the VAS (Fig. 4A,B). Masses of fine granules were fragmented in the VAS, in which virions were present in various stages of assembly (Fig. 4C). GSDIV virions had a hexagonal outline and were 180 to $200 \mathrm{~nm}$ in size. The VAS often contained tubular structures among the virions (Fig. 4A). Enlarged IBCs had many virions within the host cell cytoplasm and budding virions on the surface of the host cell cytoplasm. Some enlarged IBCs were punctured due to expansion of the inclusion body, permitting propagation of huge numbers of virions. Ballooning, degenerated IBCs had an inclusion body with the electronlucent matrix containing degenerated and fragmented organelles and a decreased number of virions in the VAS (Fig. 4D). A mass of rough granules was present within the VAS as well as fragmented masses of fine granules. In some ballooning, degenerated IBCs, both types of granular masses disappeared.

Atypical IBCs were also observed in moribund fish in the DI groups. Differing from typical IBCs, the host cell cytoplasm surrounded an unusual inclusion body, like a swollen cell in appearance, with the electron-lucent matrix containing abundant granules, fewer mitochondria and rER, and a swollen nucleus-like structure with little content (Fig. 5A). The appearance of these atypical IBCs was of a flattened cell enclosed within a swollen cell. However, in atypical IBCs, the surrounding host cell cytoplasm, together with the boundary membrane, protruded somewhat into the inclusion body, similar to the cytoplasm of typical IBCs. This feature of atypical IBCs indicated that they were 1 cell. The abnormality of the inclusion body was also substantiated by no formation of a VAS and its degeneration without virion assembly (Fig. 5B).

On the other hand, EM of IBCs of surviving fish in the PF group revealed the features of the inclusion body to be very different from that of typical IBCs (Fig. 5C). These abnormal inclusion bodies comprised the vacuolized amorphous matrix containing a small number of virions, fibrous structures, myelin-like structures and masses of fine granules while organelles such as mitochondria and rER were rare. GSIV virions were round rather than hexagonal, with an irregular amount of core (Fig. 5D).

\section{DISCUSSION}

A tissue filtrate of virus-infected fish is often used in infection experiments to determine viral pathogenicity and fish susceptibility. This is a convenient method when in vitro virus culture is not available. It is generally expected that a high concentration of virus will cause a higher mortality in a given fish than a low concentration of virus. In the present study, the results of infection experiments using a tissue filtrate containing GSDIV ran contrary to that expectation. A primary filtrate must contain larger numbers of GSDIV than $10^{-4}$ dilution. However, humpback grouper given an inoculum of $10^{-4}$ dilution displayed high mortalities (90 to $100 \%$ ) while fish injected with a primary filtrate showed much lower mortality (30 to $60 \%$ ). Moribund fish in the former experiment formed many typical IBCs propagating large numbers of virions, while surviving fish in the latter experiment formed abnormal IBCs producing few virions. The formation of different types of IBCs appeared to induce differential mortality. Electron microscope features of the IBCs were important in verifying this hypothesis. The histological features of IBCs in humpback grouper were the same as those in red sea bream Paglus major, sea bass 

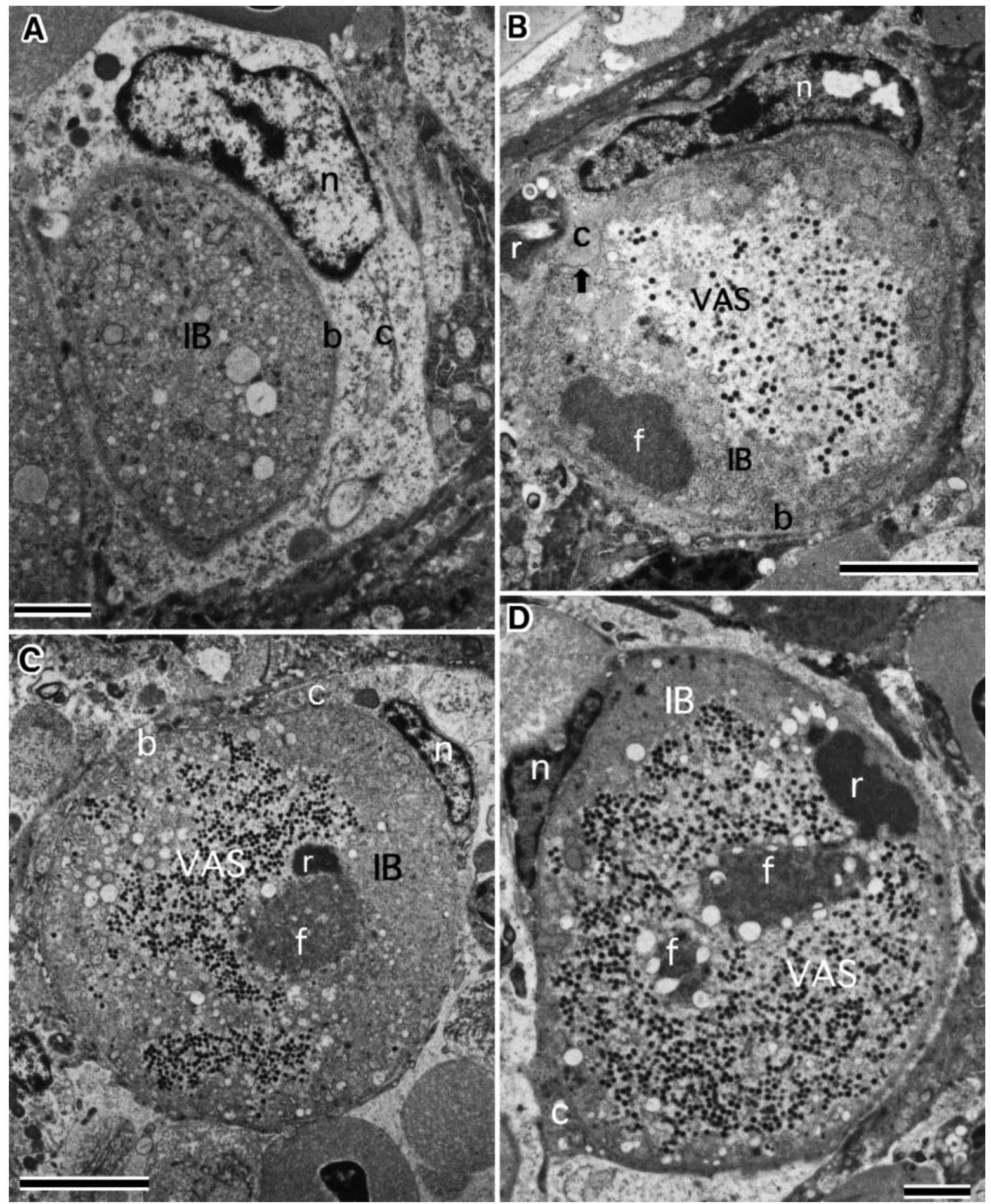

Fig. 3. Cromileptes altivelis. (A) Early stage of inclusion body-bearing cell (IBC) with small inclusion body (IB) in the cytoplasm (c) $($ scale bar $=2000 \mathrm{~nm}$ ). (B) Small mature IBC; mass of rough granules (r) is present in cytoplasm of the host cell; inclusion body contains mass of fine granules (f) among abundant organelles and a virus assembly site with propagated virions (scale bar $=3600$ $\mathrm{nm}$ ). (C) Mature IBC with large inclusion body containing masses of fine granules (f) and rough granules (r) beside developed virus assembly site (VAS) with many virions (scale bar $=5000 \mathrm{~nm}$ ). (D) Mature IBC with enlarged inclusion body; developed VAS contains masses of fine granules among propagated virions; mass of rough granules is present beside VAS (scale bar $=2000 \mathrm{~nm}$ ). b: boundary membrane; c: cytoplasm of host cell; f: mass of fine granules; IB: inclusion body; n: nucleus of host cell; r: mass of rough granules; VAS: virus assembly site; arrow in (B): cytoplasmic protrusion into inclusion body 

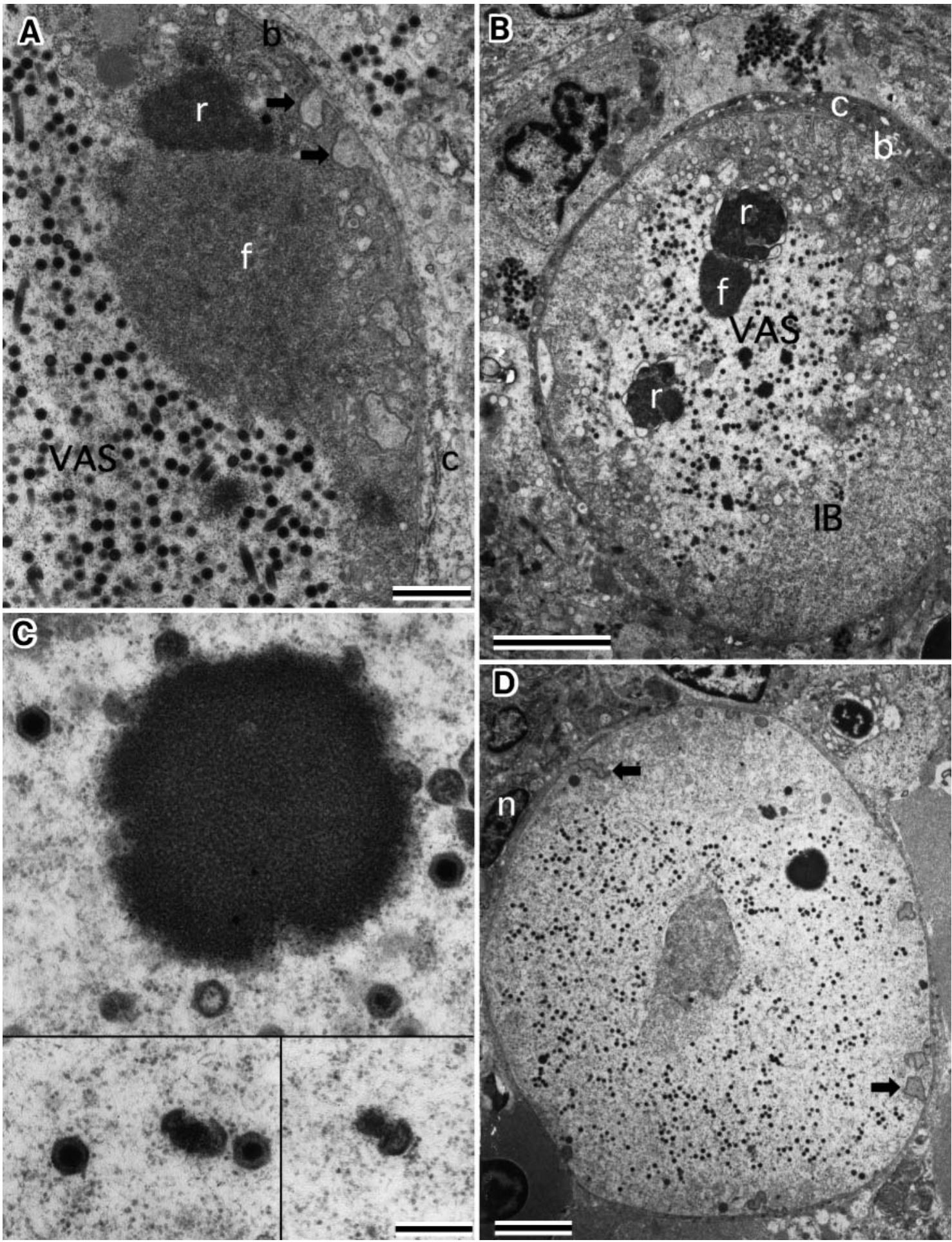

Fig. 4. Cromileptes altivelis. (A) Detail of inclusion body of mature IBC; host cell cytoplasm together with the boundary membrane protrudes into the inclusion body (arrows); masses of fine and rough granules have developed and penetrated the VAS, where similar fine granules are abundant; VAS contains many hexagonal virions, 180 to $200 \mathrm{~nm}$ in size, and a few tubule-like structures (scale bar $=1200 \mathrm{~nm}$ ). (B) Mature IBC showing virions released from the marginally compressed cytoplasm of the host cell; masses of fine granules have been fragmented within the VAS (scale bar $=4000 \mathrm{~nm}$ ). (C) Detail of virion assembly in mass of fine granules within the VAS (scale bar $=400 \mathrm{~nm}$ ). (D) Ballooning degenerated IBC; within inclusion body, all organelles are degenerated and fragmented, mixing with virions and granular masses (scale bar $=4400 \mathrm{~nm}$ ). Abbreviations as in Fig. 3 

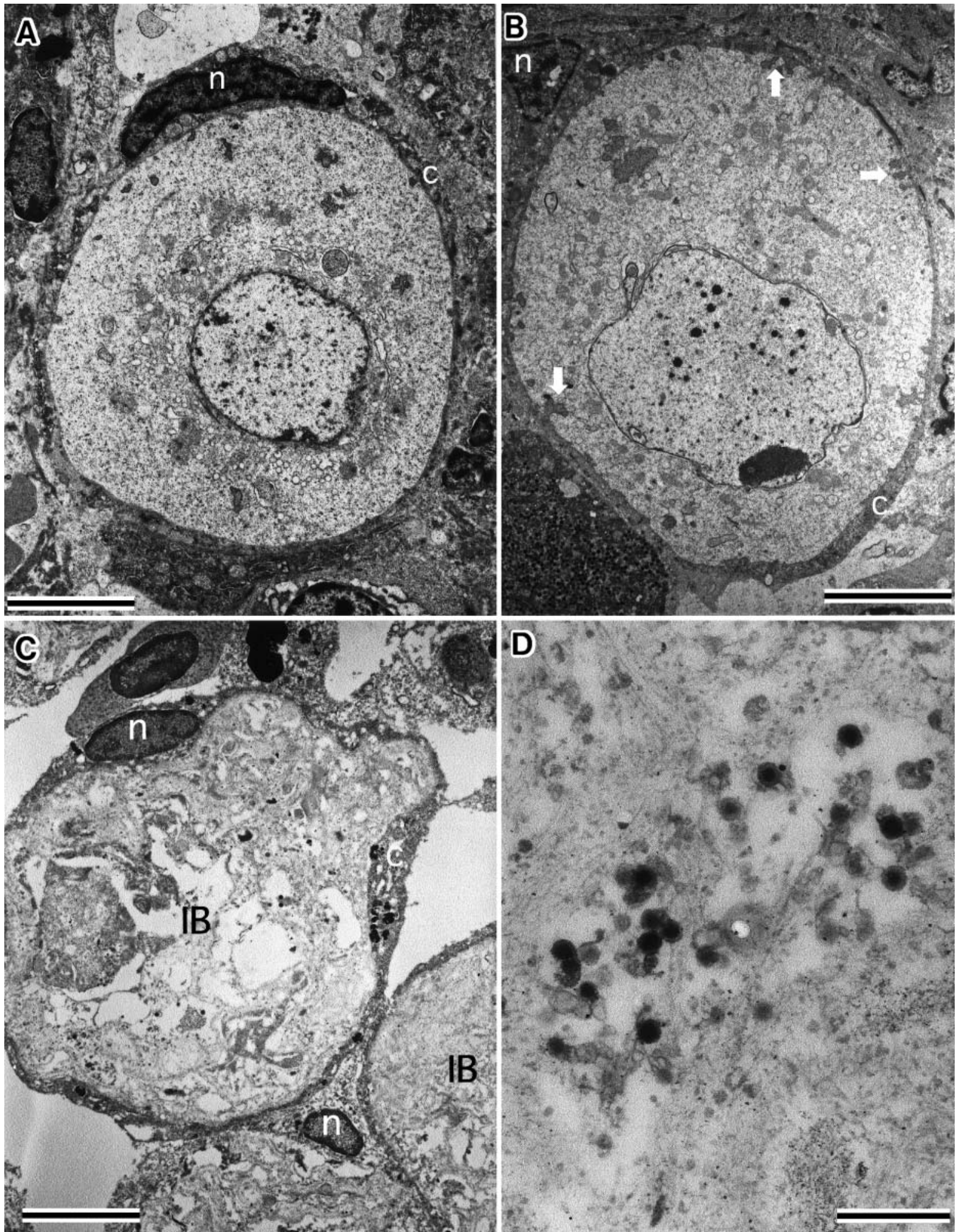

Fig. 5. Cromileptes altivelis. (A) Atypical IBC of moribund fish from diluted injection (DI) group, containing unusual inclusion body (scale bar $=5000 \mathrm{~nm}$ ). (B) Atypical IBC of moribund fish from DI group with degenerated inclusion body (scale bar = $6000 \mathrm{~nm}$ ). (C) Abnormal IBCs in surviving fish injected with primary filtrate; IBCs produced an abnormal inclusion body with a paucity of virions (scale bar $=4000 \mathrm{~nm}$ ). (D) Detail of abnormal inclusion body in (C), showing deformed and incomplete virions (scale bar $=600 \mathrm{~nm})$. Abbreviations as in Fig. 3 
Lateolabrax sp., African lampeye Aplocheilichthys normani and dwarf gourami Colisa lalia infected with tropical iridovirus (Sudthongkong et al. 2002a,b) as well as grouper fishes with the iridovirus infection: brown-spotted grouper (Chua et al. 1994), Malabar grouper (Danayadol et al. 1997, Sano et al. 2002), cultured groupers (Chou et al. 1998), orange-spotted grouper (Maharadika et al. 2001) and hybrid grouper (red spotted grouper Epinephelus akaara $\times$ Malabar grouper) (Chao et al. 2002). The electron microscope features of enlarged cells of grouper species have not been completely investigated. Typical IBCs of humpback grouper were mostly the same as those found in other fishes such as red sea beam, etc. (Sudthongkong et al. 2002a,b). The host cell of the early-stage IBCs contained a small inclusion body that was not included within a phagosome, indicating that it had been formed within the host cell but not phagocytized. A similar formation of an inclusion body was also observed in flounder fibrocytes just after infection with Lymphocystivirus in the family Iridoviridae (Miyazaki \& Oota 2002). In IBCs, the inclusion body was delimited from the surrounding cytoplasm of the host cell by a membranous boundary. The membrane allowed the host cell cytoplasm to protrude into the inclusion body. This indicated that an inclusion body was delimited with a boundary membrane but maintained a good connection with the host cell cytoplasm. Masses of 2 types of granules were observed in mature IBCs in which many virions were propagated within the VAS. Within/beside the VAS, masses of fine granules formed, upon which virions assembled, similar to virion assembly reported for Lymphocystivirus (Yamamoto et al. 1976, Tanaka et al. 1985, Miyazaki \& Oota 2002). Therefore, the fine granules would appear to be GSDIV DNA. On the other hand, a mass of rough granules appeared in the host cell cytoplasm and in the marginal region of inclusion body. Within the inclusion body, masses of fine granules of GSDIV DNA were formed close beside the mass of rough granules. The rough granules appear to be the template of virus DNA and might be propagated in the host cell nucleus and moved into the cytoplasm. When the mass of rough granules consisting of the template DNA penetrated the inclusion body, it included part of the boundary membrane. Similar granular masses observed in an enlarged cell of Malabar grouper experimentally infected with cultured RSIV were stated to comprise a degenerated nucleus (Sano et al. 2002). On the other hand, a similar mass of enlarged cells of TGIV-infected grouper was revealed to contain TGIV DNA by in situ hybridization using DNA probes for TGIV by Chao et al. (2002), who also reported it to comprise a nucleus. Considering the present EM observations of typical
IBCs, the in situ hybridization-labeled mass reported by Chao et al. (2002) could represent the granular mass associated with viral DNA but not a nucleus in the present study. Thus, the inclusion body of typical IBCs was completed for the propagation of large numbers of virions.

On the other hand, surviving fish injected with the primary filtrate formed IBCs, but all had an abnormal inclusion body containing a small number of deformed virions, while none had granular masses associated with viral DNA and organelles. The virions were determined to be GSDIV based on the results of a routine PCR diagnosis, which indicated that GSDIV infected cells and induced them to produce an IBC. However, the inclusion body was incomplete and produced only a small number of abnormal virions. Therefore, extensive virus dissemination did not occur, probably enabling survival of the fish. This prevention of virus assembly was not an effect of a putative antibody, since no type of IBC was found in humpback grouper immunized with a formalin-killed RSIV vaccine (Miyazaki unpubl. data). Although the existence of fish interferon has not been proved, prevention of virus assembly in the host cells is recognized, because of the effect of interferon in mammals (Imanishi 1997). In the present study, moribund fish also displayed atypical IBCs that degenerated without virus assembly. This indicated that a previously unknown substance with an interferon-like effect, inhibiting virus assembly, was produced in the spleen before the fish became moribund. In infection experiments, a filtrate containing GSDIV was obtained from the spleen of orangespotted grouper moribund after GSDIV injection. If the donor fish had produced a substance with an interferon-like effect in the spleen, the filtrate would contain it. The primary filtrate prepared using the spleen from donor fish was speculated to contain enough of this substance to enable it to be passed on to the injected fish in the PF group. This resulted in the prevention of virus propagation within the IBCs and contributed to survival. On the other hand, in the DI group, a diluted inoculum may have diluted the concentration of the substance to low or absent. Since the diluted inoculum contained fewer virions, the reduced amount or absence of the substance did not induce IBCs to inhibit virus propagation. Therefore, severe virus dissemination occurred at an early infection stage, resulting in the massive formation of IBCs and high mortality.

The present infection experiments suggested that mortality independent of the putative virus concentration occurred when a filtrate of spleen tissues containing virus was used as an inoculum. It should be ensured that fish contain this substance with an interferon-like effect in future studies. 


\section{LITERATURE CITED}

Chao CB, Yang SC, Tsai HY, Chen CY, Lin CS, Huang HT (2002) A nested PCR for the detection of grouper iridovirus in Taiwan (TGIV) in cultured hybrid grouper, giant seaperch, and largemouth bass. J Aquat Anim Health 14: $104-113$

Chou HY, Hsu CC, Peng TY (1998) Isolation and characterization of a pathogenic iridovirus from cultured grouper (Epinephelus sp.) in Taiwan. Fish Pathol 33:201-206

Chua FHC, Ng ML, Ng KL, Loo IJ, Wee JY (1994) Investigation of outbreaks of a novel disease, 'sleepy grouper disease', affecting the brown-spotted grouper Epinephelus tuvina Forskal. J Fish Dis 17:417-427

Danayadol Y, Direkbusarakom S, Boonyaratpalin S, Miyazaki T, Miyata M (1997) Iridovirus infection in brown-spotted grouper (Epinephelus malabaricus) cultured in Thailand. In: Flegel TW, MacRae IH (eds) Diseases in Asian aquaculture. III. Asian Fisheries Society, Singapore, p 67-72

Imanishi J (1997) Interferon. In: Hatanaka S (ed) Virology. Asakura-shoten, Tokyo, p 158-165 (in Japanese)

Jung SJ, Miyazaki T, Miyata M, Danayadol Y, Tanaka S (1997) Pathogenicity of iridovirus from Japan and Thailand for the red sea bream Pagrus major. Fish Sci 63: 735-740

Kasornchandra J, Khongpradit R (1996) Isolation and preliminary characterization of a pathogenic iridovirus in nursing grouper, Epinephelus malabaricus. Thail Natl Inst Coast Aquacult Tech Paper 5:14

Kurita J, Nakajima K, Hirono I, Aoki T (1998) Polymerase chain reaction (PCR) amplification of DNA of red sea bream iridovirus (RSIV). Fish Pathol 33:17-23

Mahardika K, Koesharyani I, Sugama K, Priyono A, Yuasa K (2001) Histopathological study of iridovirus infection in Epinephelus coioides and Epinephelus bleekeri. Proceedings of Mariculture Technology and Sea Farming Development. Jakarta, Indonesia. Japan International Coopera-

Editorial responsibility: Jo-Ann Leong,

Kaneohe, Hawaii, USA tion Agency, Jakarta, p 334-341 (in Indonesian with English abstract)

Miyata M, Matsuno K, Jung SJ, Danayadol Y, Miyazaki T (1997) Genetic similarity of iridoviruses in Japan and Thailand. J Fish Dis 20:127-134

Miyazaki T, Oota S (2002) Ultrastructures of lymphocystis cells in Japanese flounder Paralichthys olvaceus. Bull Fac Bioresour Mie Univ 29:21-30

Nakajima K, Maeno Y, Yokoyama K, Kaji C, Manabe S (1998) Antigen analysis of red sea bream iridovirus and comparison with other fish iridovirus. Fish Pathol 33:73-78

Nishizawa T, Mori K, Nakai T, Furusawa I, Muroga K (1994) Polymerase chain reaction (PCR) amplification of RNA of striped jack nervous necrosis virus (SJNNV). Dis Aquat Org 18:103-107

Sano M, Minagawa M, Nakajima K (2002) Multiplication of red sea bream iridovirus (RSIV) in the experimentally infected grouper Epinephelus malabaricus. Fish Pathol 37:163-168

Sudthongkong C, Miyata M, Miyazaki T (2002a) Iridovirus disease in two ornamental tropical freshwater fishes: African lampeye and dwarf gourami. Dis Aquat Org 48:163-173

Sudthongkong C, Miyata M, Miyazaki T (2002b) Viral DNA sequences of genes encoding the ATPase and the major capsid protein of tropical iridovirus isolates which are pathogenic to fishes in Japan, South China Sea and southeast Asian countries. Arch Virol 147:2089-2109

Tanaka M, Yoshimizu M, Kusakari M, Kimura T (1985) Lymphocystis disease in kurosoi Sebastes schegeli and hirame Paralichthys olvaceus in Hokkaido, Japan. Bull Jpn Soc Sci Fish 50:37-42 (in Japanese with English abstract)

Yamamoto T, Macdnald RD, Gillespie DC, Kelly RK (1976) Viruses associated with lymphocystis disease and dermal sarcoma of walleye (Stizostedion vitreum vitreum). J Fish Res Board Can 33:2408-2419

Submitted: May 10, 2003; Accepted: October 22, 2003

Proofs received from author(s): March 12, 2004 